\author{
ADAM BOGACZ ${ }^{1 *}$, MARIA ANDRZEJCZAK ${ }^{1}$, KLARA TOMASZEWSKA $^{2}$, MAGDA PODLASKA $^{2}$ \\ ${ }^{1}$ Wroctaw University of Environmental and Life Sciences, Institute of Soil Science and Environmental Protection \\ Grunwaldzka Str. 53, 50-357 Wroctaw, Poland \\ ${ }^{2}$ Wrockaw University of Environmental and Life Sciences Institute of Botany and Plant Ecology \\ Grunwaldzka Str. 24a, 53-363 Wroctaw, Poland
}

\title{
Anthropogenic impact on concentration of selected trace elements pools in transformed organic soils in Trzcińskie Mokradła Peatland, SW Poland
}

\begin{abstract}
Drainage and peat extraction may have a negative impact on existing hydrological conditions and, consequently, on the conditions of wetland ecosystems. The aim of this study was to assess human impact on the studied Trzcińskie Mokradła Peatland by comparing the concentrations and trace element $(\mathrm{Pb}, \mathrm{Zn}, \mathrm{Cu}, \mathrm{Cr}$ and $\mathrm{Ni}$ ) pools in the study area (extracted vs. nonextracted areas of peatland). The concentration of trace elements in organic soils and their pools were analysed in relation to their depth in the soil profiles, content of organic matter, soil $\mathrm{pH}$ values and the degree of decomposition of organic materials (peat, mursh). Fifteen soil profiles (90 samples) were examined. The total soil elements content was determined after digestion in a mixture of $\mathrm{HCl}+\mathrm{HNO}_{3}$. The element pools were calculated and expressed in $\mathrm{g} \mathrm{m}^{-2}$ of soil in $0-30 \mathrm{~cm}$ and $30-50 \mathrm{~cm}$ layers. Soils showed acidic or slightly acidic reactions. The high concentrations of $\mathrm{Pb}$ and $\mathrm{Zn}$ were mainly observed in the upper horizons. The deeper layers enriched with mineral fractions were also enriched in metals like $\mathrm{Cr}$ and $\mathrm{Ni}$.
\end{abstract}

Keywords: organic soils, trace elements, peatland, mursh, peat extraction

\section{INTRODUCTION}

The majority of organic soils in peatlands can be preserved for thousands of years in good condition in North American and Eurasian lowlands (Lappalainen 1996), valleys (Van Bellen et al. 2016) and European mountain regions (Shotyk 1995). These situation are very important for the use these soils in paleoenvironmental works (Godwin 1981). Peatland soils are archives of natural peatland development and human activity and history (Shotyk et al. 1998). Trace elements in peat soils and the their different concentrations can be used as a database to understand and demonstrate both natural and human-induced changes of elements in the ecosystem air, soil and water (Shotyk et al. 2005). Organic soils and trace elements can be used as proxies to study climate change and paleoclimatic variation (Martinez Cortizas et al. 2002) and future climatic change scenarios (Martinez et al. 1997). They can also be useful for studying paleoindustry, smelting/mining (Chambers and Chaman 2004), agriculture (Chambers 2003) and forestry use (Pitman 2006) as well as pollution history (Fiałkiewicz-Kozieł et al. 2018), geoarcheology (Jenkins 1995) and reconstruction of vegetation changes (Monna et al. 2004).
For decades, the Jelenia Góra Basin has been a part of the industrial emission impact zone, which in many regions of the Sudetes is one of the main causes of changes in the soil environment (Brogowski et al. 1997). Trace element accumulation in peatlands were a result of air pollution and dust particles transported by the wind (Błaś and Sobik 2003), fuel combustions (Jones and Hao 1993) and sometimes genesis (Rood et al. 1995). Particles containing trace elements float in the air and are deposited on the plants and the soil in dry and wet conditions (Lin et al. 2009). Trace elements concentrations could also be the result of waterborne terrestrial mineral or biogenic particles (Bjork 1993). In the course of railway rolling stock operation soil material is subjected to abrasion and deposit of fuel burning products of diesel-electric locomotives (Wiłkomirski et al. 2011). High local concentration of trace elements could also be a result of the presence of wild waste dumps near studied peatland (Kaszubkiewicz et al. 2011).

Peat extraction (Silvola et al. 1996) and peatlands drainage (Wessolek 1999; Jutras and Plamandon 2005; Nieminen et al. 2005; Glina et al. 2016a, 2017a, 2018; Bogacz et al. 2017; Zawieja and Glina 2017) can lead to the changes of hydrological conditions, properties of organic soils and, consequently, soil nutrient status 
(Rydin and Jeglum 2006). The drainage of the Trzcinskie Mokradła Peatland started in the 19th century and was carried out due to forest cultivation and peat extraction (Staffa 1999). The interference in hydrological stability of peatland has often led to many changes in wetland soil properties (Bogacz 2005; Kucharczyk and Szary 2012; Glina et al. 2016b, Glina et al. 2019). The concentration and pools of trace elements could be also connected with peat soil transformation (Kabała and Szerszeń 1998; Glina and Bogacz 2013; Glina et al. 2016c, 2017b). The aim of this paper was to assess the variability of the concentrations of trace elements pools in two analysed layers $(0-30 \mathrm{~cm})$ and $(30-50 \mathrm{~cm})$ in organic soils of the previously pristine peatland partially transformed by human activities (drainage, and peat extraction).

\section{MATERIALS AND METHODS}

The study area included a part of Trzcińskie Mokradła peatland (Poland, N 50.52', E 15.54') covering the area of 36.64 ha at the altitudes 390 to $397 \mathrm{~m}$ a.s. 1. The study area is administrated by the State Forests National Forest Holding (Śnieżka Forest District, Janowice and Śnieżka Forest Units). Similar peatlands, located in the Jelenia Góra mountain basin, have rarely survived because of medieval settlement and agricultural use (Staffa 1999).

The peatland studied has developed on the low to high impermeable, granite and greenstone clays and loam bedrock (Narkiewicz 1999) formed with solifluction and colluvial processes (Bogacz 2000). The high ground water levels were the result of this lithological and geological situation (Kondracki 1998). According to Tarasiewicz (2002), the genesis of the studied peatlands was influenced by the presence of several sources of groundwater (soligenous and lithogenous). Despite the abovementioned ground water system impact, nowadays rain and surface water play the leading role in forming of the hydrological conditions of the study area (Jezierski 2002). The northern peatlands areas are the headwaters for the Silnica stream (Narkiewicz 1999). Peatland was previously described as a transitional peatland (Schube 1903), the thickness of which only rarely exceeded $100 \mathrm{~cm}$ (Bogacz et al. 2016). Today Trzcińskie Mokradła Peatland represents two different trophic statuses: more oligotrophic in the larger part in the north, and more minerotrophic in the small part in the south. Based on the chemical composition of the water (Andrzejczak and Bogacz 2013), the peatland has been classified as a weakly minerotrophic fen according to the classification proposed by Rydin and Jeglum (2006).

The organic soils of the drained peatlands parts are currently influenced by forest and meadow communities (Andrzejczak and Bogacz 2013). We have observed the expansion of forest communities with predominating spruce and birch especially in more drained areas. The following peatland plant communities were identified in 2008: Scheucherio-Caricetae, Vacinio-uliginosi-Betuletum pubescens, Sphagno recurvi-Eriophoretum angustifoli, Alnetea glutinosae,

TABLE 1. Geographic coordinates and classification of the studied Trzcińskie Mokradła soils

\begin{tabular}{|c|c|c|c|c|}
\hline \multirow[t]{2}{*}{ Profile } & \multirow[t]{2}{*}{ Geographic coordinates } & \multirow[t]{2}{*}{ Soil units WRB 2015} & Soil Type & Subtype \\
\hline & & & \multicolumn{2}{|c|}{$\begin{array}{l}\text { proposal of English equivalents for the soil... } \\
\text { (S witoniak et al. 2016) }\end{array}$} \\
\hline TM 1 & 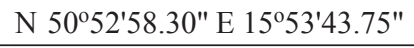 & Hemic Histosol Dystric & Hemic peat soils & Sapri-hemic peat soils \\
\hline TM 2 & N 5052'59.66" E 155'59.24" & Hemic Histosol Dystric & Hemic peat soils & Sapri-hemic peat soils \\
\hline TM 3 & N 5052'54.78" E 1553'59.07" & Murshic Histosol Dystric & Murshic soils & Sapri-murshic soils \\
\hline TM 4 & 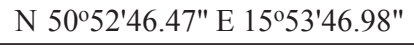 & Murshic Histosol Dystric & Murshic soils & Sapri-murshic soils \\
\hline TM 5 & 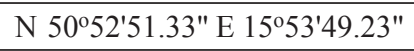 & Murshic Histosol Dystric & Murshic soils & Sapri-murshic soils \\
\hline TM 6 & 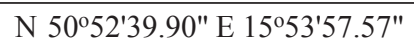 & Fibric Histosol Dystric & Fibric peat soils & Limni-fibric peat soils \\
\hline TM 7 & 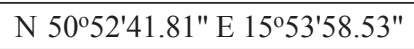 & Murshic Histosol Dystric & Murshic soils & Sapri-murshic soils \\
\hline TM 8 & 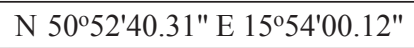 & Sapric Histosol Dystric & Sapric peat soils & Simni-sapric peat soils \\
\hline TM 9 & 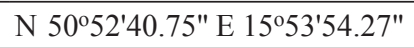 & Hemic Histosol Dystric & Hemic Histosol Distric & Sapri-hemic peat soils \\
\hline TM 10 & N 505'41.29" E 155'58.29" & Fibric Histosol Dystric & Fibric peat soils & Fibri-sapric peat soils \\
\hline TM 11 & N 505' $44.97^{\circ}$ E $15^{\circ} 54^{\prime} 04.42^{\prime \prime}$ & Sapric Histosol Dystric & Sapric peat soils & Fibri-sapric peat soils \\
\hline TM 12 & N 5052'59.05" E 155'52.78" & Hemic Histosol Dystric & Hemic peat soils & Sapri-hemic peat soils \\
\hline TM 13 & 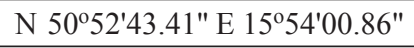 & Fibric Histosol Dystric & Fibric peat soils & Fibri-sapric peat soils \\
\hline TM 14 & N 505'ㄷ․ & Fibric Histosol Dystric & Fibric peat soils & Fibri-sapric peat soils \\
\hline TM 15 & N 50'53'00.12" E $15^{\circ} 53^{\prime} 47.70^{\prime \prime}$ & Fibric Histosol Dystric & Fibric peat soils & Fibri-sapric peat soils \\
\hline
\end{tabular}




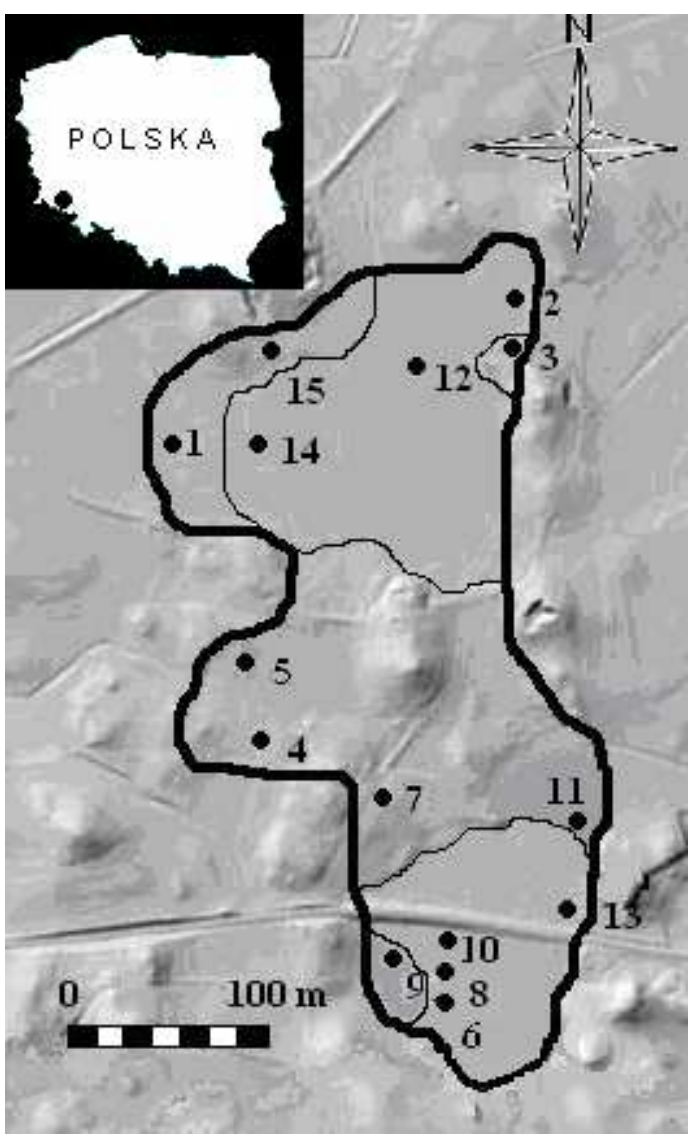

FIGURE. Location of study area within the border of Poland and examined profiles within the studied Trzcińskie Mokradła peatland. Profile $\mathrm{N}^{\mathrm{o}} \mathrm{s} 1,3,4,5,7,9,11$, and 15 represent nonextracted areas. Profile $\mathrm{N}^{\circ}$ s 2, 6, 8, 10, 12, 13, and 14 represent extracted area, $\boldsymbol{m}$ border of peatland, - border of extracted/non extracted peatland area, (source: geoportal.gov.pl)

Filipendulion ulmarie and meadows with the Calthion group (Bogacz et al. 2016). No information exists regarding plant communities from the period prior to the peat extraction and drainage.

Exploitation of the examined peatland area was carried out on a small scale in the late $19^{\text {th }}$ and early 20th centuries (Staffa 1999). Anthropogenic landscape modification in form of peat pits and ditch arrangements is documented in old maps (Zimmerman and Berg 1941). We can still observe these landscape changes in the self-restoring, central part of the peatland (Bogacz et al. 2016) and murshed organic soils along the peatland borders (Andrzejczak and Bogacz 2013). The major part of the peatland is still drained with a network of ditches (Woźniak 2007).

During field studies, 15 organic soil profiles were examined using an Instorf peat auger (Horawski 1987). Profiles $\mathrm{N}^{\circ} .1,3,4,5,7,9,11$ and 15 represent non extracted parts of the peatland and profiles $\mathrm{N}^{\circ} .2,6$, $8,10,12,13$ and 14 represent the extracted parts of the peatland. Profile locations and borderlines of extracted peatland areas are identified on the LIDAR based image in Figure (Geoportal.gov.pl 2013). In many post-extraction sites, the restoration of peatforming processes was observed. Peat extraction was also confirmed by $\mathrm{C}^{14}$ dating of profile $\mathrm{N}^{\circ} .14$ (Bogacz et al. 2016). Peat transformation (mursh forming process) in drained areas of the non-extracted part of peatland is represented by profiles $\mathrm{N}^{\circ} .3,4$, and 5 . Ninety samples were collected (74 organic and 16 mineral samples). Peat samples were divided into two parts, of which one was dried at room temperature $\left(18-20^{\circ} \mathrm{C}\right)$ and another one was preserved wet and refrigerated at $4^{\circ} \mathrm{C}$. The part of soil samples in natural structure were collected in $100 \mathrm{~cm}^{-3}$ metal rings for measuring soil bulk densities. Dry samples were ground and sieved through an ø $2 \mathrm{~mm}$ sieve.

In the dry samples, the following properties were determined: ash content by ignition in furnace at $550^{\circ} \mathrm{C}$ for 4 hours, total organic carbon (TOC) by catalytic dry combustion at $600^{\circ} \mathrm{C}$ in Ströhlein CS-Mat 5500 . The total content of trace elements $(\mathrm{Zn}, \mathrm{Pb}, \mathrm{Cu}, \mathrm{Ni}$, $\mathrm{Cr}$ ) was determined after the microwave sample digestion in the mixture $\mathrm{HNO}_{3}+\mathrm{HCl} 3: 1$ and measured using atomic absorption spectrometry (AAS) (Soil Survey Staff 1998). In wet soil material, which had been refrigerated at $4^{\circ} \mathrm{C}$, the following properties were determined: peat decomposition based on volume of unrubbed fibre (UF) isolated by the half syringe method (Lynn et al. 1974), and potentiometric soil $\mathrm{pH}$ in soil to water and soil to $1 \mathrm{~mol} \mathrm{dm}^{-3} \mathrm{KCl}$ solutions at 1:2.5 ratios (v/v) (PN-ISO 10390: 1998). The pools of trace elements in $0-30 \mathrm{~cm}$ and $30-50 \mathrm{~cm}$ layers were calculated based on the thicknesses of particular layers and their calculated bulk densities. The depths of sampling layers were connected with peat excavation depths which probably were about 30-40 cm (Bogacz et al. 2016) and organic soils depths. Selected elements pools M (g) accumulated in soil within each of soil layer on the surface $\mathrm{S}$ $\left(\mathrm{S}=1 \mathrm{~m}^{2}\right)$ were calculated as:

$$
\mathrm{M}\left(\mathrm{g} \mathrm{m}^{-2}\right)=\mathrm{C}\left(\mathrm{g} \mathrm{kg}^{-1}\right) \mathrm{S}\left(\mathrm{m}^{2}\right) \mathrm{d}(\mathrm{cm}) \sigma\left(\mathrm{g} \mathrm{cm}^{-3}\right)
$$

where: $\mathrm{M}$ is pools of element, $\mathrm{C}$ is element concentration $\left(\mathrm{mg} \mathrm{kg}^{-1}\right), \mathrm{d}$ is depth of soil layer, and $\sigma$ is soil dry bulk density.

In this study, pools of trace elements were not used to determine the utility aim of these soils. Determination of elements pools in this case was used to compare soils of extracted and non-extracted areas of peatland.

Arithmetical means and Pearson's correlation coefficients for the relationships with environmental parameters were calculated based on laboratory analysis results. All calculations were conducted using 
Statistica 10.0 software. Differences between pools of elements in $0-30 \mathrm{~cm}$ and $30-50 \mathrm{~cm}$ core depths were calculated using the mean standard deviation (SD) and basic analysis of variance coefficients (CV).

\section{RESULTS AND DISCUSSION}

Organic soils were classified to Histosols with the main qualifiers Fibric, Hemic, Sapric, Dystric, and Murshic, or Drainic and supplementary qualifiers Fluvic and Mineralic (IUSS-WRB 2015). According to the Proposal of English Equivalents for Polish Soils Classification soil system names (Świtoniak et al. 2016), they were described as Fibric, Hemic and Sapric peat soils or Murshic soils. Soil profiles with disturbed layer sequences and those not exploited were described by measuring the thickness of the layers from the current soil surface. During previous years, the organic matter accumulation has continued on most of the studied peatland surface (Bogacz et al. 2016). Soil morphology, genesis and properties of the studied profiles have already been partly presented (Andrzejczak and Bogacz 2013; Bogacz et al. 2016) and some of these results are briefly given in Table 2 . The thickness of some of the organic soil profiles was strongly reduced by manual peat cutting (Zimmerman and Berg 1941). Organic soils profiles in historical mining areas have had a hiatus (Bogacz et al. 2016).

Unrubbed fibre (UF) is one of the most important organic material decomposition factors (Soil Survey Staff 1999). The content of unrubbed fibre ranged from $0 \%$ in mursh horizons to $87 \%$ in fibric peat horizons. (Table 2). The presence of strongly decomposed peat is sometimes connected with the water transport humic substances, mineral fraction and the fibric peat drainage (Paivanen and Hanell 2012). The degree of peat decomposition, expressed by volume of the unrubbed fibre (UF), significantly changed with depth $\left(\mathrm{r}=-0.54^{*}, \mathrm{n}=90, \mathrm{p}<0.05\right)$. Content of TOC ranged from $4.30 \mathrm{~g} \mathrm{~kg}^{-1}$ in the mineral horizon to $621 \mathrm{~g} \mathrm{~kg}^{-1}$ in organic horizons consisting of sapric peat (Table $2)$. The increase in carbon content in upper organic horizons was strongly associated with the presence of unrubbed fibre $\left(r=0.45^{*}, n=90, p<0.05\right)$ (Table 4). Reaction of peat soils was acidic or strongly acidic. Strongly silted organic soils were generally less acidic than the others (Bogacz et al. 2012). There was a significant negative correlation between the values of soil reaction $\mathrm{pH}$ and the content of TOC $\left(\mathrm{r}=-0.43^{*}\right.$, $\mathrm{n}=90, \mathrm{p}<0.05$, Table 4).

The lead content in the examined samples ranged from 2.0 to $136 \mathrm{mg} \mathrm{kg}^{-1}$ in organic horizons. Measured lead content was higher in upper horizons than in the deeper horizons $\left(-0.38^{*}, \mathrm{n}=90, \mathrm{p}<0.05\right.$, Table 4$)$.

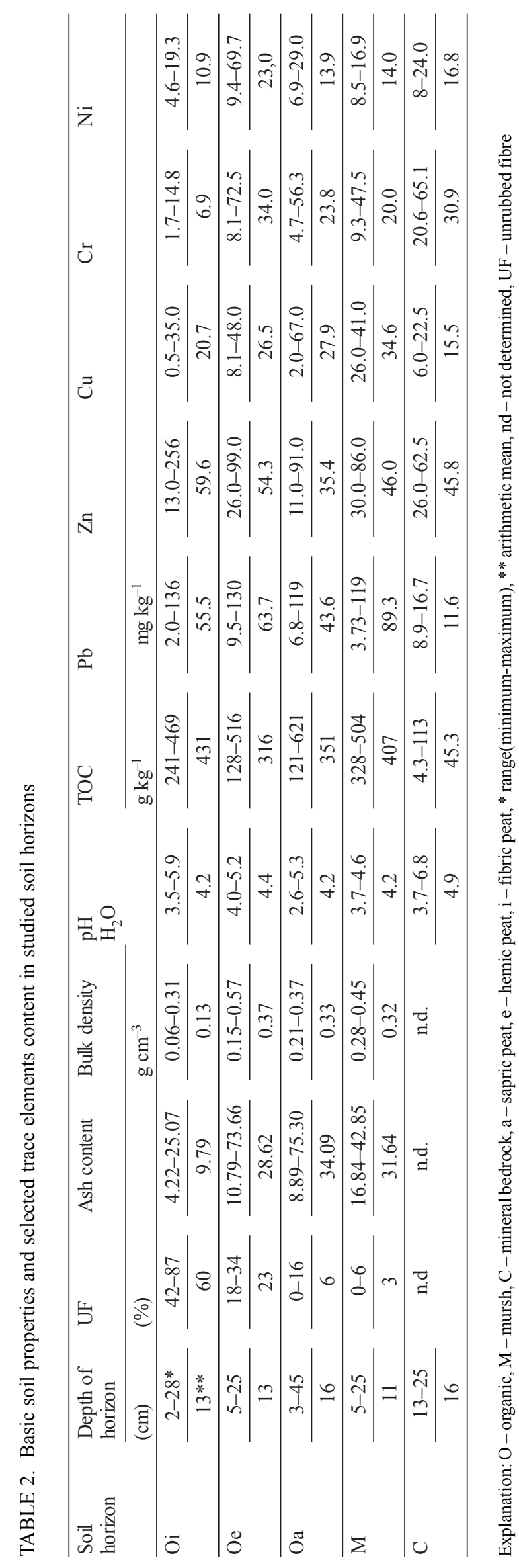


TABLE 3. Trace elements pools in soil horizons in Trzcińskie Mokradła Peatland

\begin{tabular}{|c|c|c|c|c|c|c|c|c|c|c|c|}
\hline \multirow[t]{2}{*}{ Profile } & \multirow{2}{*}{$\begin{array}{l}\text { Layer } \\
\mathrm{cm}\end{array}$} & \multicolumn{10}{|c|}{ Trace elements (total forms) $\mathrm{g} \mathrm{m}^{-2}$} \\
\hline & & $\mathrm{Pb}$ & & $\mathrm{Zn}$ & & $\mathrm{Cu}$ & & $\mathrm{Cr}$ & & $\mathrm{Ni}$ & \\
\hline \multirow[t]{2}{*}{ TM1* } & $0-30$ & 4.56 & & 1.59 & & 1.26 & & 0.87 & & 1.33 & \\
\hline & $30-50$ & 2.14 & 6.70 & 3.32 & 4.91 & 1.61 & 2.87 & 3.05 & 3.92 & 2.52 & 3.85 \\
\hline \multirow[t]{2}{*}{ TM2 } & $0-30$ & 1.52 & & 2.21 & & 0.47 & & 0.19 & & 0.31 & \\
\hline & $30-50$ & 0.22 & 1.74 & 0.66 & 2.87 & 0.21 & 0.68 & 0.19 & 0.38 & 0.15 & 0.46 \\
\hline \multirow[t]{2}{*}{ TM3* } & $0-30$ & 13.0 & & 5.41 & & 3.39 & & 1.70 & & 1.21 & \\
\hline & $30-50$ & 3.97 & 17.0 & 7.44 & 12.8 & 4.05 & 7.44 & 7.50 & 9.20 & 3.06 & 4.27 \\
\hline \multirow[t]{2}{*}{ TM4* } & $0-30$ & 7.90 & & 5.48 & & 3.42 & & 1.64 & & 1.37 & \\
\hline & $30-50$ & 1.18 & 9.08 & 2.49 & 7.97 & 1.52 & 4.94 & 2.04 & 3.68 & 1.59 & 2.96 \\
\hline \multirow[t]{2}{*}{ TM5* } & $0-30$ & 5.49 & & 2.08 & & 2.27 & & 0.69 & & 0.90 & \\
\hline & $30-50$ & 1.23 & 6.72 & 1.05 & 3.13 & 1.69 & 3.96 & 1.05 & 1.74 & 1.01 & 1.91 \\
\hline \multirow[t]{2}{*}{ TM6 } & $0-30$ & 1.68 & & 5.67 & & 0.99 & & 1.53 & & 0.64 & \\
\hline & $30-50$ & 1.94 & 3.62 & 4.88 & 10.55 & 2.48 & 3.45 & 6.74 & 8.27 & 2.45 & 3.09 \\
\hline \multirow[t]{2}{*}{ TM7* } & $0-30$ & 4.20 & & 3.18 & & 1.16 & & 0.31 & & 0.46 & \\
\hline & $30-50$ & 1.30 & 5.50 & 0.95 & 4.13 & 0.57 & 1.73 & 0.19 & 0.50 & 0.17 & 0.63 \\
\hline \multirow[t]{2}{*}{ TM8 } & $0-30$ & 2.10 & & 1.78 & & 2.11 & & 0.19 & & 0.31 & \\
\hline & $30-50$ & 0.61 & 2.71 & 2.80 & 4.58 & 0.60 & 2.71 & 0.19 & 0.38 & 0.15 & 0.46 \\
\hline \multirow[t]{2}{*}{ TM9* } & $0-30$ & 3.14 & & 2.04 & & 0.70 & & 0.26 & & 0.29 & \\
\hline & $30-50$ & 2.32 & 5.46 & 2.04 & 4.08 & 0.25 & 0.95 & 0.18 & 0.44 & 0.27 & 0.56 \\
\hline \multirow[t]{2}{*}{ TM10 } & $0-30$ & 0.39 & & 1.07 & & 0.64 & & 0.12 & & 0.22 & \\
\hline & $30-50$ & 4.83 & 5.22 & 4.06 & 5.13 & 3.81 & 4.45 & 2.43 & 2.55 & 1.62 & 1.84 \\
\hline \multirow[t]{2}{*}{ TM11* } & $0-30$ & 1.24 & & 2.44 & & 1.14 & & 0.60 & & 0.51 & \\
\hline & $30-50$ & 1.57 & 2.81 & 5.59 & 8.03 & 2.66 & 3.80 & 5.00 & 5.69 & 2.13 & 2.64 \\
\hline \multirow[t]{2}{*}{ TM12 } & $0-30$ & 4.72 & & 3.57 & & 1.30 & & 0.34 & & 0.52 & \\
\hline & $30-50$ & 1.51 & 6.23 & 1.90 & 4.66 & 0.66 & 1.96 & 0.23 & 0.57 & 0.20 & 0.72 \\
\hline \multirow[t]{2}{*}{ TM13 } & $0-30$ & 2.69 & & 3.83 & & 2.11 & & 1.61 & & 1.03 & \\
\hline & $30-50$ & 2.11 & 4.80 & 3.85 & 7.68 & 1.89 & 4.00 & 2.65 & 4.25 & 1.34 & 2.37 \\
\hline \multirow[t]{2}{*}{ TM14 } & $0-30$ & 1.68 & & 1.75 & & 1.11 & & 1.53 & & 0.76 & \\
\hline & $30-50$ & 1.94 & 3.62 & 4.88 & 6.63 & 2.48 & 3.59 & 6.74 & 8.27 & 2.39 & 3.15 \\
\hline \multirow[t]{2}{*}{ TM15* } & $0-30$ & 0.36 & & 1.13 & & 0.60 & & 0.12 & & 0.20 & \\
\hline & $30-50$ & 3.07 & 3.43 & 2.44 & 3.57 & 2.30 & 2.90 & 1.26 & 1.38 & 0.93 & 1.13 \\
\hline
\end{tabular}

Explanation: * extracted.

TABLE 4. Correlation coefficients between some properties of soils studied

\begin{tabular}{|c|c|c|c|c|c|c|c|c|}
\hline Value & $\mathrm{Pb}$ & $\mathrm{Cr}$ & $\mathrm{Ni}$ & $\mathrm{Cu}$ & $\mathrm{Zn}$ & $\mathrm{pH}$ & TOC & UF \\
\hline Depth & $-0.384 *$ & $0.506^{*}$ & 0.318 & -0.196 & -0.226 & 0.337 & $-0.739 *$ & $-0.540^{*}$ \\
\hline $\mathrm{Pb}$ & & -0.299 & 0.075 & $0.473 *$ & -0.040 & -0.319 & $0.445^{*}$ & 0.256 \\
\hline $\mathrm{Cr}$ & & & $0.424^{*}$ & 0.130 & -0.121 & 0.337 & $-0.694 *$ & $-0.437^{*}$ \\
\hline $\mathrm{Ni}$ & & & & 0.317 & 0.024 & 0.287 & $-0.383 *$ & -0.286 \\
\hline $\mathrm{Cu}$ & & & & & 0.031 & 0.164 & 0.210 & -0.074 \\
\hline $\mathrm{Zn}$ & & & & & & 0.204 & 0.111 & 0.153 \\
\hline $\mathrm{pH}$ & & & & & & & $-0.429 *$ & -0.185 \\
\hline TOC & & & & & & & & $0.449^{*}$ \\
\hline
\end{tabular}

Explanation: UF - unrubbed fibre, correlation coefficient significant at: ${ }^{*} \mathrm{p}<0.05, \mathrm{n}=90$. 
Organic horizons in many part of Sudetes Mountains showed a higher content of lead compared to zinc. This observation was related mainly to the Izera (Bogacz 2005; Glina and Bogacz 2013) and Stołowe Mountains (Glina et al. 2017b). This is, according to Strzyszcz and Magiera (2001), proof of the transport of contaminants over long distances. These phenomena cannot be observed in Trzcińskie Mokradła Peatland.

The $\mathrm{Zn}$ contents varied greatly and ranged from 11 $\mathrm{mg} \mathrm{kg}^{-1}$ of soil in horizons consisting of sapric peat to $256 \mathrm{mg} \mathrm{kg}^{-1}$ of soil in fibric material (Tables 1,2). Zinc showed a higher content in the subsurface soil layers, compared to the surface. This situation could be a result of high zinc mobility (McBride and Blasiek 1979).

The copper contents in organic horizons ranged from 0.5 to $67 \mathrm{mg} \mathrm{kg}^{-1}$. It was strongly correlated with $\mathrm{Pb}$ content $\left(0.47^{*}, \mathrm{n}=90, \mathrm{p}<0.05\right.$, Table 4$)$. This may indicate a wide variation in the levels of copper content of organic horizons, or it could be the result of anthropogenic impact on the examined soils. It is interesting that there was no significant correlation between the content of TOC and the total content of copper, which has a high affinity to organic substances (Kabata-Pendias and Pendias 1999).

The concentration of chromium in the analysed soil layers ranged from $1.7 \mathrm{mg} \mathrm{kg}^{-1}$ in fibric peat horizons to $72.5 \mathrm{mg} \mathrm{kg}^{-1}$ in hemic peat horizons. The same situation held for the concentration of nickel (from $4.6 \mathrm{mg} \mathrm{kg}^{-1}$ in fibric material to $69.7 \mathrm{mg} \mathrm{kg}^{-1}$ in hemic material). Chromium and nickel concentration in analysed soils samples were strongly positively correlated with TOC content: $\left(\mathrm{r}=-0.69^{*}, \mathrm{n}=90\right.$, $\mathrm{p}<0.01$ and $\mathrm{r}=-0.38^{*}, \mathrm{n}=90, \mathrm{p}<0.05$ respectively). Moreover, $\mathrm{Cr}$ content correlated with depth $\left(\mathrm{r}=0.51^{*}\right.$, $\mathrm{n}=90, \mathrm{p}<0.05)$ and unrubbed fibre content $\left(\mathrm{r}=-0.44^{*}\right.$, $n=90, p<0.05$, Table 4). Silted soil horizons generally contained significantly higher concentrations of above-mentioned elements. This phenomenon was also observed by Borowiec and Urban (2001) in organic soils of the Ciemiega River Valley. Research carried out by Arkhipov et al. (2000) showed that, over large areas of Western Siberia, chromium is a good indicator of silting processes in peat soils. Generally, the highest contents of $\mathrm{Zn}$ and $\mathrm{Cu}$ and especially of $\mathrm{Pb}$ appeared in surface horizons, while the highest contents of $\mathrm{Cr}$ were observed in deeper silted layers (Table 2).

The largest differences in contents and pools of some metals were between the upper $(0-30 \mathrm{~cm})$ and deeper layers $(30-50 \mathrm{~cm}$, Tables 3,5$)$. Content of selected elements in upper soil horizons were probably connected with peat extraction and mixing with mining materials (Bogacz et al. 2016). The largest values for calculated pools differentiations were observed in case of zinc and chromium (Tables $3,5)$. The concentrations and pools of $\mathrm{Pb}$ and $\mathrm{Cu}$ in surface layers $(0-30 \mathrm{~cm})$ were clearly higher in soil represented of profiles from non-exploited areas (Tables 3,5 ). This was most probably related to the minor mobility of these elements in the soil. A completely different situation was observed for $\mathrm{Zn}$, $\mathrm{Cr}$ and $\mathrm{Ni}$. The higher element pools were calculated for deeper, usually more silted, horizons (Tables 3, 5). The pools of all determined metal contents in horizons $0-50 \mathrm{~cm}$ of non-extracted areas were generally larger than in surface horizons within the extracted parts of peatlands (Table 3). In the subsurface soil horizons $(30-50 \mathrm{~cm})$, the average metal contents and pools were similar for the exploited and unexploited areas (Table 5).

TABLE 5. Pools of trace elements in layers $0-30 \mathrm{~cm}$ and $30-50 \mathrm{~cm}$ of extracted and non extracted peatland parts

\begin{tabular}{|c|c|c|c|c|c|c|c|c|c|c|}
\hline $\begin{array}{l}\text { Metal } \\
(\mathrm{n}=90)\end{array}$ & $\begin{array}{l}\text { Depth of } \\
\text { layer } \\
(\mathrm{cm})\end{array}$ & $\mathrm{x}$ & $\mathrm{SD}$ & $\mathrm{dx}$ & $\mathrm{CV}$ & $\begin{array}{l}\text { Depth of } \\
\text { layer } \\
(\mathrm{cm})\end{array}$ & $\mathrm{x}$ & $\mathrm{SD}$ & $\mathrm{dx}$ & $\mathrm{CV}$ \\
\hline \multirow[t]{2}{*}{$\mathrm{Pb}$} & $0-30$ & 2.11 & & & & $30-50$ & 2.09 & & & \\
\hline & $0-30 *$ & 4.99 & 3.32 & 2.88 & 0.87 & $30-50 *$ & 1.88 & 4.17 & 0.21 & 0.05 \\
\hline \multirow[t]{2}{*}{$\mathrm{Zn}$} & $0-30$ & 2.84 & & & & $30-50$ & 3.29 & & & \\
\hline & $0-30^{*}$ & 2.92 & 1.58 & 0.08 & 0.05 & $30-50 *$ & 3.16 & 1.01 & 0.13 & 0.07 \\
\hline \multirow[t]{2}{*}{$\mathrm{Cu}$} & $0-30$ & 1.25 & & & & $30-50$ & 1.72 & & & \\
\hline & $0-30^{*}$ & 1.90 & 0.95 & 0.65 & 0.68 & $30-50 *$ & 1.83 & 1.57 & 0.11 & 0.07 \\
\hline \multirow[t]{2}{*}{$\mathrm{Cr}$} & $0-30$ & 0.79 & & & & $30-50$ & 2.74 & & & \\
\hline & $0-30^{*}$ & 0.78 & 0.64 & 0.01 & 0.01 & $30-50 *$ & 2.53 & 2.64 & 0.21 & 0.8 \\
\hline \multirow[t]{2}{*}{$\mathrm{Ni}$} & $0-30$ & 0.54 & & & & $30-50$ & 1.18 & & & \\
\hline & $0-30 *$ & 0.78 & 0.41 & 0.24 & 0.58 & $30-50 *$ & 1.46 & 1.01 & 0.28 & 0.28 \\
\hline
\end{tabular}

Explanation: $\mathrm{x}$ - arithmetic means, $\mathrm{SD}$ - standard deviation, $\mathrm{dx}$ - differences of arithmetic means, $\mathrm{CV}$ - variance coefficient, * not excavated. 


\section{CONCLUSIONS}

In general, $\mathrm{Cu}$ and $\mathrm{Pb}$ pools within the studied peatland indicated greater accumulations of those trace elements in the $0-30 \mathrm{~cm}$ surface layer. The opposite situation was observed for $\mathrm{Zn}, \mathrm{Cr}$ and $\mathrm{Ni}$ pools. This phenomenon was related to different metal mobility and peat extraction.

The exploitation of peat led to a decrease in lead and copper pools in the upper layers $(0-30 \mathrm{~cm})$.

The statistically, significant differences of trace elements concentrations and pools were related to differences in soil $\mathrm{pH}(\mathrm{Cu}, \mathrm{Ni}$, and $\mathrm{Cr})$.

There was no correlation between the copper content and organic components (TOC) in the studied soils. This is an unusual phenomenon, which could be associated with disturbances of the soil horizons caused by human activity (drainage and peat extraction).

\section{REFERENCES}

Andrzejczak M., Bogacz A., 2013. Composition of humic fraction in organic soil in different parts of peatland splited by railway line. Zeszyty Naukowe Uniwersytetu Przyrodniczego we Wrocławiu 595: 7-19.

Arkhipov V.S., Bernatonis V., Rezchicov K., 2000. Distribution of iron, cobalt and chromium in peatlands of the central part of Western Siberia. Eurasian Soil Science 33(12): 42-56.

Bjork S., 1993. The Hongyuan wetland research project. An ecological and technical feasibility study of peat mining in Higyuan, Sichuan, China. Summary prepared for the Sichuan Institute of Natural Resources, Lund, Sweden: $100 \mathrm{pp}$.

Błaś M., Sobik M., 2003. Natural and Human Impact on Pollutant deposition in mountain ecosystem with the Sudetes as an example. Acta Universitatis Wratislaviensis, Geographical Studies 2542, (75): 429-438.

Bogacz A., 2000. Physical properties of organic soil in Stołowe Mountains National Park (Poland). Suo 51(3): 105-113.

Bogacz A., 2005. Properties and evolution of selected organic soils in Sudetes Mountains. Zeszyty Naukowe Uniwersytetu Przyrodniczego we Wrocławiu 507: 1-147.

Bogacz A., Andrzejczak M., Tomaszewska K., Podlaska M., 2016. Plant communities properties and age of organic soils in the post-extraction sites of the Trzcińskie Mokradła Peatland (Sudetes Mts. SW Poland). Soil Science Annual 67(2): 79-87.

Bogacz A., Dziecioł D., Glina B., Gersztyn L., 2012. Peat soil in the restoration Niknąca Ląka Peatland in the Stołowe Mountains National Park. Soil Science Annual 63(2): 3-8.

Bogacz A., Glina B., Midor A., Tomaszewska K., Podlaska M., Telega P., Dradrach A., 2017. The effect of long-term peatlands drainage on the properties of soil in microrelief in the Długie Mokradło Bog (Central Sudeties - SW Poland). Polish Journal of Soil Science 50(2): 224-237.

Borowiec J., Urban D., 2001. Stratigraphic and geochemical differentiation of organogenesis sediments in the river valley in Ciemiegga as a result of anthropogenic alterations in the area of the river basin in the Holocene. Acta Agrophysica 50: 29-40.

Brogowski Z., Borzyszkowski J., Gworek B., Ostrowska A., Porębska G., Sienkiewicz J., 1997. Soil characteristics of deforested region of the Izerskie Mountains. Soil Science Annual 48(1/2): 111-124.

Chambers F., 1983. New application of paleoecological techniques: integrating evidence of arable activity in pollen and peat and soil stratigraphies, Cefn Graenog, north Wales. [In:] Integrating the Subsistence Economy (Jones M. Editor) BAR International Series 181, Chapter 5: $16 \mathrm{pp}$.

Chambers F.M., 2003. Setting the scene. In: Murphy P. and Wiltshire P.E.J. (Eds), The Environmental Archeology of Industry. Symposia of the Association for Environmental Archeology, Oxbow, Oxford 20: 4-8.

Chambers F.M., Charman D., 2004. Holocene environmental change: Contributions from from the peatland archive. Holocene 14: $1-6$.

Fiałkiewicz-Kozieł B., Vleeschouwer F., Matoelli N., Fagel N., Palowski B.,Pazur A., Smieja-Król B., 2018. Record of Anthropocen pollution sources of lead in disturbed peatlands from Southern Poland. Atmospheric Environment 179: 6168.

Geoportal.gov.pl 2013. Main Office of Geodesy and Cartography.

Glina B., Bogacz A., 2013. Concentration and pools of trace elements in organic soils in the Izera Mountains. Journal of Elementology 18(2): 199-209.

Glina B., Bogacz A., Gulyas M., Zawieja B., Gajewski P., Kaczmarek Z., 2016a. The effect of long-term forestry drainage on the current state of peatlands soils: A case study from the Central Sudetes (SW Poland). Mires and Peat 18(21): 1-11.

Glina B., Bogacz A., Pikus M., Pawluczuk J., 2016b. Anthropogenic and weather condition impact on mineral nitrogen content in organic soils from slope fen peatland in Stołowe Mountains. Polish Journal of Soil Science 49(1): 1-13.

Glina B., Bogacz A., Woźniczka P., 2016c. Nitrogen mineralization in forestry-drained peatland soils in the Stołowe Mountains National Park (Central Sudetes Mts.). Soil Science Annual 67(2): 64-72.

Glina B., Malkiewicz M., Mendyk Ł., Bogacz A., Woźniczka P., 2017. Human-affected disturbances in vegetation cover and peatland development in the late Holocene recorded in shallow mountain peatlands (Central Sudetes, SW Poland). Boreas 46(2): 294-307.

Glina B., Bogacz A., Mendyk Ł., Bojko O., Nowak M., 2018. Effectiveness of restoration of degraded shallow mountain fen after five years. Mires and Peat 21(11): 1-15.

Glina B., Piernik A., Hulisz P., Bogacz A., Spychalski W., 2019. Water or soil - What is the dominant driver controlling the vegetation pattern of degraded shallow mountain peatlands. Land Degradation and Development 30(12): 1437-1448.

Glina B., Spychalski W., Zawieja B., Kaczmarek T., 2017 b. Spatial distribution of trace elements in the shallow mountains peatlands, the Stołowe Mountains (SW. Poland). Journal of Elementology 22(4): 1359-1375.

Godwin H., 1981. The Archive of the Peat Bogs. Cambridge University Press, London.

Horawski M., 1987. Peat science for a drainage. Basic concepts. Agriculture University of Kraków Press 37-39.

IUSS-World Resource Base of Soil Classification 2015. Polskie 
Towarzystwo Gleboznawcze. (Polish Soil Society) Torun 2015: 3-239.

Jenkins D.A., 1995. Trace element analysis in the study of ancient metallurgy. [In:] Ellis-Jones J., (Ed.), Aspects of Ancient Mining and Metallurgy, Bangor, 1986. University College, Bangor: 95-105.

Jezierski P., 2002. The chemistry of groundwater and their dynamics in the area of Rudawy Janowickie. PhD Thesis. Manuscript. Institute of Geology. University of Wrocław.

Jones J.M., Hao J., 1993. Ombrotrophic peat as medium for historical monitoring of heavy metal pollution. Environmental Geochemistry Health 15: 67-74.

Jutras S., Plamondon P.A., 2005. Water table rise after harvesting in a treed fen previously drained for forestry. Suo 56(3): 95-100.

Kabała C., Szerszeń L., 1998. Form soil iron and trace elements in strongly acidic podzols soil in Izerskie Mountains. Zeszyty Problemowe Postępów Nauk Rolniczych 456: 381-386.

Kabata-Pendias A., Pendias H., 1999. Biochemistry of trace elements. PWN: 400 pp.

Kaszubkiewicz J., Gałka B., Kawałko D., 2011. Impact of legal and illegal waste dumps on the surrounding soils in the Jelenia Góra and Wrocław Districts. Soil Science Annual 62(2): 179-188.

Kondracki J., 1998. Physical Geography of Poland. Wydawnictwo Naukowe PWN, Warszawa.

Kucharczyk S., Szary A., 2012. Degradation and protection of high peat bogs in the Bieszczady National Park. Roczniki Bieszczadzkie 20: 83-97.

Lappalainen E. (Ed). 1996. Global Peat Resources. International Peat Society. Jivaskyla: 359 pp.

Lin H., Chen L.P., Ai Y.W., Yang X., Yu Y.H., Zuo Y.B., 2009. Heavy metal contamination soil alongside mountain railway in Sichuan, China. Environmental Monitoring and Assessment 152: 25-33.

Lynn W.C., McKinzie W.E., Grossman R.B., 1974. Field laboratory tests for characterization of Histosols. [In]: Histosols: their characteristics, classification and use. (Stelly M. Editor), SSSA Special Publication 6 Madison, WI.: 11-20.

Martinez Cortizas A., Garcia-Rodeja E., Pontevedra-Pombal X., Novoa Munoz J., C., Cheburkin A., K., 2002. Atmospheric $\mathrm{Pb}$ deposition in Spain during the last 4600 years recorded by two ombrotrophic peat bog and implication for use of peat as archive. Science of the Total Environment 292: 33-44.

Martinez Cortizas A., Pontevedra-Pombal X., Novoa Munoz J.C., Garcia-Rodeja E., 1997. Four thousand years of atmospheric $\mathrm{Pb}, \mathrm{Cd}$ and $\mathrm{Zn}$ deposition recorded by the ombrotrophic peat bog of Penido Vello (Northwestern Spain). Water Air Soil Pollution 100: 387-403.

McBride M.B., Blasiek J.J., 1979. Zinc and copper solubility as a function of $\mathrm{pH}$ in acid soil. Soil Science Society American Journal 43: 866-870.

Monna F., Petit C., Guillaumet J-P., Jouffroy-Bapicot I., Blanchot C., Dominik J., Losno R., Richard H., Levegue J., Chateau C., 2004. History and environmental impact of mining activities in Celtic Aeduan territory recorded in a peat bog (Morval, France). Environmental Science Technology. 38(3): 665-673.
Narkiewicz C., 1999. Trzcińskie Mokradła Peatland in Jelenia Góra Basin. Przyroda Sudetów Zachodnich 2: 3-6.

Nieminen M., Ahti E., Nousiainen H., Joensu S., Vollekoski M., 2005. Capacity of riparian buffer to reduce sediment concentrations in discharge from peatlands drained for forestry. Silva Fennica (39)3: 331-339.

Paivanen J., Hanell B., 2012. Peatland Ecology and Forestry a Sound Approach. University of Helsinki Department of forest Sciences Publication 3: 135-154.

Pitman R., M., 2006. Wood ash use in forestry a review of the environmental impact. Forestry 79 (5): 563-588.

PN-10390, 1997. Soil quality-pH determination. Polish Norm $15 \mathrm{pp}$.

Polish Soil Classification 2011. Soil Science Annual 62(3): 1-193.

Rood B.E., Gottgens J.F., Delfino J.J., Earle C.D., Crisman T. L., 1995. Mercury accumulation trends in Florida Everglades and Savannas Morsh flooded soil. Water, Air, and Soil Pollution 80: 981-990.

Rydin H., Jeglum J., 2006. The Biology of Peatlands. The biology of habitat series, Oxford University Press: 343 pp.

Schube T., 1903. Die verbreitung der gafabplahen in Schlesien. Breslau, preußischen und österreichischen Anteils, Druck von R. Nischkarsky: 1-361.

Shotyk W., 1995. Natural and anthropogenic enrichments of As, $\mathrm{Cu}, \mathrm{Pb}, \mathrm{Sb}$ and $\mathrm{Zn}$ in ombrotrophic versus minerotrophic peat bog profiles, Jura Mountains, Switzerland. Water, Air Soil Pollution 90: 375-405.

Shotyk W., Weiss D., Appleby P.G., 1998. History of atmospheric lead deposition since 12,37014Cyr BP from a peat bog, Jura Mountains, Switzerland. Science 28: 1635-1640.

Silvola J., Alm J., Ahlholm U., Nykanen H., Martikainen P.J., 1996. $\mathrm{CO}_{2}$ fluxes from peat in boreal mires under varying temperature and moisture conditions. Journal of Ecology 84: 219-228.

Soil Survery Staff, 1999. Soil Taxonomy. A basic system of soil classification for making and interpreting soil surveys, 2nd edition. Agricultural Handbook 436. Natural Resources Conservation Service, USDA, Washington DC, USA: pp. 869.

Staffa M., 1999. Dictionary the tourist geography of the Sudeten. Jelenia Góra Basin. Wydawnictwo I-BIS 4: 518 pp.

Strzyszcz Z., Magiera T., 2001. Record of industrial pollution in Polish ombrotrophic peat bog. Physics and Chemistry on the Earth 26(11/12): 859-866.

Świtoniak M., Kabała C., Charzyński P., 2016. Proposal of English equivalents for the soil taxa names in the Polish Soils Classification. Soil Science Annual 67(3): 103-116.

Tarasiewicz P., 2002. The age of peatland near Janowice Wielkie in Jelenia Góra Basin according to the palynological survey. Institute of Geology, University of Wrocław, PhD Thesis.

Van Bellen S., Mauquoy D., Hughes P.D.M., Roland P.T., Daley T.J., Loader N.J., Strret-Perrott F.A., Rice E.M., Pancotto V.A., Payne R.J., 2016. Late-Holocene climatic dynamics recorded in the peat bogs of Tierra del Fuego, South America. Holocene 26(3): 489-501.

Wessolek G., 1999. Processes of soil formation in fen mires. Ökologische Hefte, Landwirtschaftlich Gärtnische Fakultät der Humboldt Universität zu Berlin 11: 96-122.

Wiłkomirski B., Sudnik-Wójcikowska B., Galera H., Wierzbicka M., Malawska M., 2011. Railway transportation as 
a serious source of organic and inorganic pollution. Water, Air, and Soil Pollution 218: 333-345.

Woźniak M., 2007. Trzcińskie Mokradła. Sudety, Trzcińskie Wetlands. Sudeten 2: 32-33.

Zawieja B., Glina B., 2017. Application of multivariate statistical methods in the assessment of mountain organic soil transfor- mation in the central Sudetes. Biometrical Letters 54(1): 43-59.

Zimmerman E., Berg G., 1941. Erlaterungen zu Blatt Kaufung Geol. Karte Deutsch. Reiches 1:25 000, Preussichen Geologischen Landesanstalt, Berlin.

\title{
Wpływ czlowieka na zawartość i zasoby metali ciężkich w przekształconych glebach na torfowisku Trzcińskie Mokradła
}

\begin{abstract}
Odwodnienie i eksploatacja torfu wywierają negatywny wpływ na warunki hydrologiczne i w konsekwencji na kondycję ekosystemów mokradłowych. Celem podjętych badań było określenie wpływu człowieka (wydobywcza eksploatacja torfu) na gleby organiczne torfowiska Trzcińskie Mokradła (Kotlina Jeleniogórska), w tym na zawartości i zasób wybranych metali ciężkich $(\mathrm{Pb}, \mathrm{Zn}, \mathrm{Cu}, \mathrm{Cr}, \mathrm{Ni})$. Zawartość metali ciężkich i ich zasoby w glebach organicznych analizowano w relacji do głębokości profilów glebowych, zawartości materii organicznej, pH gleby i stopnia rozkładu torfu. Zbadano 15 profilów glebowych (90 próbek). Zasoby metali ciężkich w glebie przeliczano i wyrażano w gramach na $\mathrm{m}^{2}$ gleby w dwóch wyznaczonych poziomach $(0-30 \mathrm{~cm}$ i $30-50 \mathrm{~cm}$ ). Badane gleby wykazywały kwaśny lub lekko kwaśny odczyn. Duża zawartość $\mathrm{Pb}$ i Zn była obserwowana głównie w poziomach powierzchniowych. Głębsze poziomy wzbogacone we frakcje mineralną były także wzbogacone w metale, takie jak chrom i nikiel. Standardy jakości gleb nie zostały przekroczone na badanym torfowisku.
\end{abstract}

Słowa kluczowe: gleby organiczne, pierwiastki śladowe, torfowisko, mursz, eksploatacja torfu 